\title{
BRAND PERSONAL LEADER: Social Construction Nurdin Basirun, Governor of the Government Riau Islands Province Period 2016-2021
}

\author{
Rina Dwi Lestari \\ Student of Doctor Study Program of Administration Sciences - FISIP, \\ Universitas 17 Agustus 1945 Surabaya, Jl. Semolowaru No. 45 Surabaya, \\ Jawa Timur, Indonesia \\ Burhan Bungin \\ Lecturer in Communication Studies at Ciputra University \\ V. Rudy Handoko' \\ Head of the Administrative Sciences Study Program, \\ Universitas 17 Agustus 1945 \\ Surabaya \\ Jl. Semolowaru No. 45 Surabaya, Jawa Timur, Indonesia \\ Ute Chairus Nasution
}

\begin{abstract}
Egalitarian leaders in public leadership are the phenomena raised in this study. Nudin Basirun is a phenomenon of egalitarian leaders who are close to the people, serve the community, have attitudes and actions and programs that inspire other leaders in Riau Islands. Thus the style of leadership Nurdin Basirun has become a personal brand for him in leading the Riau Islands, since he became Deputy Regent of Karimun until now the Governor of Riau Islands. This study examines how the community constructs Nurdin Basirun's personal brand image, forms Nurdin Basirun's personal brand image and benefits of the personal brand for public leadership in Riau Islands. Using paradigm postpostivism with qualitative descriptive research methods. In data collection, researchers interviewed 10 informants and in the data analysis researchers used social construction theory as an analytical tool. This study produced research findings; 1) the community constructs Nurdin Basirun's personal brand image as an egalitarian leader with characteristics a) having spritualis, b) being loved by the community, c) being able to motivate the community, d) being a source of inspiration, e) becoming a Malay community icon of Riau Islands. 2) The process of constructing Nurdin Basirun's personal brand image by the Riau Islands community takes place in simultaneous social processes of institutionalization, legitimacy and socialization. The results of this study criticize the results of Rony Setiawan's research, Suryana Sumantri, Tb. Zulrizka Iskandar, Marina Sulastiana, (2015) about the characteristics of egalitarian leadership namely spiritualism, love and community building. The criticism of the study this time complements the characteristics of the egalitarian leader with Nurdin Basirun's special characteristics of having strength; (a) able to motivate the people, (b) be a source of inspiration and (c) become an icon, or a raw modle of society and work programs for city / regency leaders in Riau Islands.
\end{abstract}

Keywords: Public leadership, brand personal, social construction, egalitarian leaders

DOI: $10.7176 /$ PPAR/10-9-10

Publication date:September $30^{\text {th }} 2020$

\section{A. INTRODUCTION}

Direct election of regional heads as a manifestation of democracy in Indonesia has resulted in regional heads nominating as regional head candidates to change the mindset of the campaign concept because the people who make the choice, then the elected candidates must be able to be qualified leaders from the level education and competence are expected to be able to elevate the dignity of the people, and be able to carry out obligations in the implementation of regional autonomy. When we talk about leaders, it always touches on the part of their personality which involves how they control or govern others, persuade them, influence, and lead them. Personality can be defined as a person's profile or a combination of nature and uniqueness and their interactions with others. Various ways and strategies are taken to build a good image in the public eye so that all political leaders believe that the importance of building a brand for one's political career, not least Nurdin Basirun who has won regional elections several times as well as leading regional government both at the district level and in the Province. The leader figure is a combination of regulating one's physical and mental characteristics. There are a number of prospects for the future look, whether they can be permanent or developed; whether they are innate or can be formed by experience (Yukl, 2005: 231-232). 
The use of brands for people known as personal branding is increasingly common since decades of phenomena are used in various aspects, for entertainers, athletes, writers, general managers, business owners and politicians, and have spread many others to different positions in the company. The definition of brand leader (manager) given by Senge, (1990: 229) has five personal skill disciplines that include an explanation of the truth of loyalty, authority, decision making, infrastructure innovation and improving personal and interpersonal skills.

Leaders are those who lead us and who will take us to our destination. In reality the implementation of public leadership relating to planning, implementing and evaluating policies is very close to these three realities. The community often builds a subjective reality of what the leader does as a reality that is urgently needed, very close to the community, clean in its implementation, and very honest in its evaluation. But on the other hand, the community often deconstructs the subjective reality of holding public leadership with other realities which are said to be objective realities. People often talk based on reality on objective reality that is seen, witnessed and experienced in the field. So these two realities are built on the basis of their respective interests, namely the interests of the public leadership in one party and the interests of the community as the subject of development on the other.

Based on the description, the researcher will analyze the personal brand of the leader and the success of leading the local government (social construction of nurdin basirun, governor of the Riau Islands provincial government for the period 2016-2021) here will be discussed further on how the leader's process naturally builds its brand, and how the community constructs the brand leader, and how the constructed leader brand is beneficial for leadership in local government, in the spirit of business development success in the Riau Islands region.

\section{B. REVIEW OF THEORY}

\section{Constructivist paradigm}

In general, in the social sciences there are two major paradigms, namely the positivistic paradigm and the interpretive paradigm (Poerwandari, 1998). One of the paradigms in social science is administration science, one approach to contemporary research categories is constructivism. In the administrative paradigm (Hidayat, 1999), the results of this study strengthen the constructivism paradigm in which social reality is seen as a result of social construction, where the truth of a social reality is relative.

The positivistic and interpretive paradigms have a foothold assumption in assessing reality phenomena in research. A number of studies with positivist approaches as "real" disclosures of facts are governed by certain universally valid rules. While research using a constructivist approach, facts are constructs of reality. The truth of a fact is relative, applies according to certain contexts (Eriyanto, 2002).

Unlike the positivist approach, it is more likely to see a fact as it is and one direction and more objective. Conversely, the constructivist approach has another perspective, looking at a reality as part of the construction of reality. Any events or facts are interpreted in such a way according to their own experience and knowledge.

\section{Social Construction Theory}

The term construction of social reality has become famous since it was introduced by Peter L. Berger and Thomas Luckmann through his book The Social Construction of Reality: A Treatise in the Socialogical of Knowledge (1996). The social process is described through actions and interactions, in which individuals create continuously a reality that is owned and experienced together subjectively.

In the theory and social construction approach to reality, according to Peter L. Berger \& Luckmann explained it occurs simultaneously through three social processes, namely externalization, objectivation, and internalization. These three processes occur among individuals one with other individuals in society. The substance of theory and the social construction approach to the reality of Berger and Luckmann is on simultaneous processes that occur naturally through language in everyday life in a primary and semisecondary community (Burhan, 2008).

\section{Social Construction in Public Administration}

To understand the complexity of society, we need to reframe the approach of public administration. One task is to reexamine (and interpret) the concept of public administration by considering at least two important dimensions of public administration: (1) public administration is carried out in the context of society, especially in the context of democracy and civil society; and (2) administrative activities must be carried out and design choices must be made through the participation and interaction of several actors who will be involved in policies or programs (Burhan, 2018: 49).

Jun (2005), introduces a new perspective on the study and understanding of public administration by describing it in a larger and global social context. Jun sees social construction, not only related to public administration, not just a matter of policy, but also bureaucracy, administrative action, change, rigid hierarchy and ethical responsibility. Because there is no state space without social construction, state-citizen relations are strategic relations in the social construction process (Burhan, 2018: 136).

\section{Leadership in Public Administration}

In the twenty-first century, a shift in the diversity of actors, contexts and paradigms in public administration presents different challenges for leadership (Heifetz, Linsky, and Grashow 2009; Terry 1995; Van Wart 2003). Leadership such as "implements a variety of complex and mutually influencing forces of interaction" (Uhl-Bien, 
Marion, and McKelvey, 2007: 302). Some existing literature on the concept of leadership in public administration includes serving leadership. There are seven Leadership behaviors that serve as the core the process of leadership that serves as explained by Rendy and Roy (2014), namely:

1) Conceptual Skills

meaning that a serving leader cannot only see the problem from one side but see from the side of the problem.

2) Emotional Healing

This includes recognizing member problems and being willing to spend time on member problems.

3) Putting Subordinates First (Prioritizing Members)

Placing the interests and success of members is more than the interests and success of leaders (Northouse, 2013 in Rendy \& Roy, 2014).

4) Helping Subordinates Grow and Succeed (Helping Members Grow and Succeed)

Helping the career development of community members as a priority, including assisting by providing community members with assistance (Wilkes, 2005 in Rendy \& Roy, 2014).

5) Behaving Ethically

Hold very strong ethical standards, including in terms of being open, honest and fair with members (MacArthur, 2008 in Rendy \& Roy, 2014).

6) Empowering

Build members' confidence in the capacity to think and act on their own because members are given the freedom to deal with difficult situations in ways that members think is best (Northouse, Vol 6, 2013 in Rendy \& Roy, 2014).

7) Creating Value for the Community (Creating Value for Communities)

Larry Spears (1995, 2002 in Rendy \& Roy, 2014) says that serving leaders accept responsibility for managing carefully the members and organizations or companies they lead.

Rony's research, Suryana, TB Zulrizka and Marina (2015) concluded that there is a service leadership relationship and public service performance, namely 1) There is a significant positive effect on servant leadership on public service performance. 2) Three dimensions that have the greatest influence on the performance of public services are spirituality, love and community building. The leadership profile of the servants of public officials shows that there are still their efforts to serve the needs of others (subordinates and the community).

\section{Image of the Leader's Personal Brand}

Related to image understanding (Arifin, 2003), that is, the image comes from the Javanese language, which means image. Then it was developed into an image as an equivalent word image in English. So, political imagery can be understood as someone's description of politics (power, authority, authority, conflict and consensus).

According to Dan Nimmo (2000) and Arifin, (2003), a person's image will help in understanding, evaluating, and identifying events, ideas, goals, or leadership. The image also helps a person in providing subjectively acceptable reasons about why everything is present as it seems about the political preferences of society. Political imaging plays an important role because it can help understanding, evaluating audiences towards imaging objects. Indirectly packaging in imaging can help someone to be accepted into a social group.

In connection with that, Burhan (2018) said that the constituent social image construction in relations with the state-society consists of two images, namely the leader image and the image of public policy. If both images are categorized as in the table below.

Table 1 Leader's Image and Policy

\begin{tabular}{|l|l|l|}
\hline NO & \multicolumn{1}{|c|}{ IMAGE OF LEADERS } & IMAGE OF PUBLIC POLICY /PROGRAMS \\
\hline 1. & Image of Hero & Image of Benefits \\
\hline 2. & Image of Effective & Image of Scientist \\
\hline 3. & Image of Egaliterian & Image of Productive \\
\hline 4. & Image of Agitator & Image of Protector \\
\hline 5. & Image of Protector & Image of Egalitarian \\
\hline 6. & Image of Opologist & Image of Victory \\
\hline
\end{tabular}

Sumber: Burhan, B. (2018)

Indeed, everything requires branding in everyday life. Products require a brand image to be different and 'visible' than other products. Humans need branding so that people use themselves or their careers as brands. Personal Branding is how we market ourselves to others, as stated by Peter Montoya in his book "The Brand Call You" (2005). Furthermore, it is said that personal branding is a process that will bring a person's skills, personality and unique characteristics and then wrap them into identities that have more strength than competitors. The leader who is able to carry out the steps of social construction of his image will make it easier for him to build a personal brand, as the term used by Burhan (2018). So basically the life of the head of state and regional head every day at any time is a process of forming a personal brand which also means our self-image or "price" (Motoya, 2005).

\section{RESEARCH METHODS}

This research is in favor of the post-positivism paradigm (Burhan, 2018). The considerations and reasons for 
choosing the post-positivism paradigm are; (1) the problem and the purpose of this study view social phenomena that occur as systematic symptoms; (2) to obtain data in research, researchers make direct observations and interviews with informants within the framework of scientific processes as required by the post-positivism paradigm, namely there is a relationship between researchers and research subjects, so researchers are able to understand and interpret how social actors reproduce their social world which researchers observe; (3) in reality, the relationship between individuals and their social environment also relates to other documentation materials as documents stored by the community. This material is also studied by researchers to obtain a complete understanding of the activities of social actors (communities) in their overall social environment; (4) in analyzing the data, from the beginning of the study to the end of the study, that is, since the initial data was obtained, collected various data and information as well as other sources of knowledge, researchers tried to build an induction thinking framework, which then compared with social construction theory and theory others used in this study.

This study uses a qualitative approach, which is a suitable approach for understanding deeply social or humanitarian problems (Creswell, 2003). The researcher used a qualitative approach as a consequence of the position of the paradigm which considers reality to be double-faced. The approach based on qualitative studies is similar to the perspective depiction to see reality trends and explain the various processes that occur in them. In addition, it can also explain the context that occurred or part of the background of the process.

The logic of thinking in this study uses inductive logic, which is the method of scientific thinking to understand reality that starts from data and then gradually formulates more abstract scientific information. The data and information in this study on the analysis of the contents of the leader starts from a specific aspect, towards data and information that are of a general nature, widely looking at and analyzing the dynamics of social construction of reality. In the research related to the social reality of Riau Islands Province, how was the social construction of the leader brand image carried out by the people of Riau Islands against the image of Nurdin Basirun.

In addition to using inductive thinking, this research is also descriptive. According to Nazir, (1988) descriptive research describes the problems in society, as well as the procedures that apply in society and certain situations, including about relationships, activities, attitudes, views of phenomena. In descriptive research the researcher presents an event or situation.

\section{DISCUSSION}

The governor's political actor is an actor of public administration, according to Jun (2006) that in reality where his action is a social reality of public administration or the reality of bureaucracy. This Jun's view comes from the view of social construction Berger and Luckmann (1991), namely social reality constructed in the social processes of individuals, groups and society.

As Berger and Luckmann said about social construction of reality, it takes place in the process of socialization externalization, legitimacy and socialization, that the process takes place through social processes; institutionalization, legitimacy and socialization (ILS). The ILS social process is carried out through other simultaneous processes namely externalization, objectivation and internalization (EOI). So according to Berger and Luckmann that social construction of reality is a simultaneous and multilayered social process through ILSEOI (Berger and Luckmann, 1967). So the social construction of public administration (Jun, 2006) takes place through the ILS-EOI social process (Berger and Luckmann, 1967 in Burhan, 2018).

According to (Burhan, 2018) basically in social processes, social construction is constructed by other individuals or other deliberate groups (constructors) or other forces that are not intentional but occur in the social process. The attitude of acceptance or rejection of the public and other social institutions towards the administration of public administration starting from planning, implementation to evaluation depends on how the bureaucracy that organizes public administration carries out social construction on the reality of the public administration it carries out. In fact, Nurdin Basirun's Brand Personal image is a leadership image constructed by the people of Riau Islands. That in fact what Nurdin Basirun did was a personal behavior of Nurdin Basirun that was created from his daily experience as a Malay society that loved his people. The social process of Nurdin Basirun with the Riau Islands community was constructed by the community as an egalitarian leader, a leader who served the community and leaders who were loved by the majority of the people.

It was realized that initially Nurdin Basirun's personal brand image had not existed or had not yet been formed, nor was it known to exist because even social interaction had not been built in that direction. In other words, public awareness of Nurdin Basirun's brand image reality has not yet been built. Based on the results of framing and interviews with informants, it is known that the process of forming the social construction of Nurdin Basirun's brand image can be explained as follows:

1. Relationship between Karimun community and Nurdin Basirun

Karimun Regency community is the initial medium of social construction, where the beginning of Nuridn Basirun was born and enlarged in a Malay culture. He grew up as an ordinary young man who had to go to school, recite and he chose to work as a sailor. Nurdin Basirun. Helmi, biographer Nurdin Basirun explained in an interview that: 
Nurdin Basirun, as a child, has been taught how to deal with life challenges, such as selling cakes that were acted by Nurdin Basirun when he was in elementary school, both at school and outside school hours. "(Informant 10, interview 22 December 2018).

According to the informant, a major change occurred in the life of Nurdin Basirun when deciding to enter the world of youth organizations. Even though Nurdin Basirun did not have any political knowledge, including public communication at that time was very limited. Here's Helmi's explanation:

At that time Nurdin Basirun was finally interested in becoming an activist at GAPPENSI, KADIN, REI, KNPI and AMPI. From this point, the instinct to lead Nurdin Basirun was born and encouraged him to lead the Karimun community ... At the encouragement of relatives and acquaintances of Nurdin Basirun, he made a determination to participate competently in the Karimun District Regent and Deputy Regent election exchange in 1999 (Informant 10, interview 22 December 2018) .

When becoming the Deputy Regent of Karimun, the Karimun community began Nurdin Basirun's leadership as a model of egalitarian leadership, leadership that served the community, leadership that was close to the community. In connection with this Informant 9 says:

One when I lost my mind, I really wanted to know what Pak Nurdin was like, not only met Batam but I was desperate to go to Tanjung Balai Karimun, without promises, came there, from the port via a taxi driver, he knew Pak Nurdin's house, huh You know because the regent of Karimun, two periods, arrived there, then through the PP Satpol, who guarded it, would you like to meet Pak Nurdin, he brought my name in, waited for almost half an hour, entered meeting with him, and something that made I did not forget that, he gave the tea the same for fried rice, it did not know me yet. Three years ago, I didn't know me yet (interview, 31 De Sember 2018).

Nurdin Basirun's leadership style that he never forgets and makes people sympathetic to him is how he helps people with sincerity and even shamelessly he often opposes protocol rules in serving the community. Explained by Informant (2):

Then there were floods, what was called the rivet tidal flood, Tanjung Batu every year, I was reprimanded by the DPRD chairman, when I was a scholar, he was rice mackerel, for the ungar river people, pacitan trenches, hanging trenches I didn't sink the village, so he said to his friend, "please prepare rice to the promontory, then I will bring it" there is no car, can't enter, take the rice, I will. I got a hearing, in 2006, there were still pak ras, pak nanang, still alive, I got a hearing, "you are an echelon 2 scholar, well, you understand the laws that apply in the protocol, you are regulated by law, that is the UN's decision, why is your regent lifting rice using pikul, where is the case, where is the head of his office, because of my hearing ", sir, we forbid sir," what he said ", "the community needs fast, don't wait for people, we are strong, "I lifters of goods on board, "he took the die, that. For soup kitchens, at midnight until for public kitchens, rice has arrived, friends bring it from the city of Tanjung Batu, wait for it, until the community eats, wait for him. He borrows rice until I get a hearing with the council, no responsibility, Mr. Adnan Chair, Pak Ras, Pak Nanang, who is the other one, oh Iye three, I am a scholar, what is our connection with, we are administration with the leadership of the board members, I got a hearing, because I went along, join this, "we go there, all of us call, we go to Tanjung Batu, we flood, we sink in village, whether we eat or not parents". Go away, right, because there are two people there, sir, race with Pak Nanang (native of Tanjung Batu). Then, remember I'm Pak Ashura, cook the regent you leave, "cellphone work", complaining ... said one council member again, "we have banned", "well you don't let him lift the gun". Because of my hearing, the next day I get a hearing, this doesn't happen, I said with the chairman, the vice chairman "allow me, you speak directly, do I never suggest with him," don't take it "' Don't hold it "we holding (interview, 3 December 2018)

Nurdin Basirun did not hesitate to bear rice assistance to his people on the islands, he opposed the protocol because he considered helping people who were almost starving more important than just his position as an official.

The ways Nurdin Basirun serves the community makes him increasingly known by his community as an egalitarian leader, a leader who serves the community with all his heart. When Nurdin Basirun became Governor of Riau Islands, an egalitarian leadership style and serving the community, paying attention to people's aspirations, always close to the people, always serving and visiting the community made him more known in the community, all informants interviewed acknowledged egalitarian leadership style, serving style and close to this community is a community constructing Nurdin Basirun as an egalitarian leader and serving the community.

2. The Kepri community is Nurdin Basirun's personal brand image construction medium

The Kepri community itself is an important medium in the role of Nurdin Basirun's personal brand image as an egalitarian leader. The social construction process of Nurdin Basirun's personal brand image takes place in 3 stages.

According to Berger and Luckmann (1960), there are 3 stages in the process of social interaction. Stage of 
institutionalization process. The stage of forming the reality of Persdanal Nurdin Basirun's brand image (Burhan, 2008). Both stages of the process are legitimacy (Berger and Luckmann, 1960) and the three stages of the socialization process (Berger and Luckmann, 1960).

1) Institutionalization Phase

The Riau Islands community uses the stages of social construction Berger and Luckmann (1960) in constructing Nurdin Basirun's personal brand image. Based on interviews with informants, Nurdin Basirun's personal brand image began to be known to the public, since before he became the Deputy Regent of Karimun. Since he had gone to school he was like that, always had a high social character. In this case, Basyaruddin Idris (Oom) said:

His character from the beginning until now has not changed, all the while, in a while he is firm. In the next few times he reads the situation, he likes friends, looking after friends. So the meaning of the word is strict, for example if you ship, bang our ship this way huh, "No need". The language is short "no need", in no need for him to be firm, how to say it softly. If we walk too, he says "I am capable of you no need". So this character, we admit he has just extraordinary social, from ... before ... I tell you a little, don't need to be on the boat, if you don't need to ask, if you drink, drink a village if you are near Raye, especially the time when he was deputy regent (interview, 21 December 2018).

When he became the Deputy Regent of Karimun, Nurdin Basirun's behavior remained like that too, in his regard for other people, Basyaruddin Idris (Oom) explained:

He sometimes, with our own eyes, this is Bang deng's character, if the driver is busy, he doesn't bother, can he take the transport ride. Hah, he is a deputy regent, that's the case at Karimun. At that time the driver was not wrong. So because he is lazy lazy he is looking for a backup driver, it is easy if the vice regent. He called transport, transported him to PN, the district head's office. So that's the figure of him (interview, December 21, 2018).

2) The legitimacy stage

Along with the institutionalization process, namely externalization and objectivation according to Berger and Lukcmann (1960), at the same time there was also a process of legitimacy (the process of repeated justification of Nurdin Basirun's personal brand image) where institutionalization was legitimized or justified by people's logical explanations of leadership style Nurdin Basirun.

The process of Nurdin Basirun's personal brand image institutionalization also occurs through an objectivation process carried out by the Riau Islands community towards the image of Nurdin Basirun, where an image institution (egalitarian) as a class representation institutionalized by the Riau Islands itself becomes an objective reality.

3) Socialization Phase

The next process is the confirmation stage wherein the process occurs internalization through socialization where Nurdin Basirun's personal brand image institution is internalized by the Riau Islands community through a process of socialization. At this stage the community developed a continuous opinion about Nurdin Basirun's personal brand image.

This confirmation process is also carried out continuously by the community so that this process can be maintained by socialization to new members. Nurdin Basirun's personal brand image is socialized by the Riau Islands community with language institutions so that they can also be socialized to family institutions, community institutions, social media and others. The process of socialization (this) occurs through internalization, where humans become products of society. The internalization process transmits the institution of egalitarian image Nurdin Basirun as a stand-alone reality especially to new members of the community, so that Nurdin Basirun's egalitarian image institution can be maintained from time to time, including community members who conceptualize the institution to internalize so that the status of Nurdin's egalitarian image institutions Basirun in their consciousness is still positioning. The third process of forming the egalitarian image of Nurdin Basirun is a simultaneous dialectic of the individual-community relations of the Riau Islands. Individuals form the community of Riau Islands and conversely the people of Riau Islands form individuals in the Kepri community.

Based on the analysis of the frame table, it can be concluded that Nurdin Basirun's frame of Personal Brand image is (1) having a spiritualist, (2) being loved by the community, (3) being able to motivate the community, (4) being a source of inspiration, (5) being the icon of the Riau Kepri community.

The Kepri community constructs the image of an egalitarian brand to Nurdin Basirun as Governor of Riau Islands, namely an egalitarian leader, a leader who serves and is close to the community. The community also constructs egalitarian Nurdin Basirun as a leader who has spirituality, serves and loves and is loved by the community, is always close to the community, is able to motivate the community and become an icon of the community of Riau Islands.

Egalitarian Nurdin Basirun exceeds the egalitarian character of Rony Setiawan's research, Suryana Sumantri, Tb. Zulrizka Iskandar, Marina Sulastiana, (2015) namely spiritualists, love and community building. The difference in egalitarian Nurdin Basrun besides having a spiritualist, love and community building, also has 
strength; (1) motivation and (2) the strength of being an icon, or the community's raw modle and regional leadership work program.

\section{E. CONCLUSION}

Based on the explanation above, in this study it was proven that:

1) Meaning of the Image of an Egalitarian Brand Nurdin Basirun

Based on the description above, that society has interpreted Nurdin Basirun's leadership style as an egalitarian leadership style.

Based on the analysis of the frame tables above, it can be concluded that Nurdin Basirun's frame of Personal Brand image is (1) having spritualism, (2) being loved by the community, (3) being able to motivate the community, (4) becoming a source of inspiration, (5) being a community icon Malay Kepri.

Kepri community constructs the image of an egalitarian brand to Nurdin Basirun as Governor of Riau Islands, namely egalitarian leaders, leaders who serve and are close to the community. The community also constructs egalitarian Nurdin Basirun as a leader who has spirituality, serves and loves and is loved by the community, is always close to the community, is able to motivate the community and become an icon of the community of Riau Islands.

Egalitarian Nurdin Basirun exceeds the egalitarian character of Rony Setiawan's research, Suryana Sumantri, Tb. Zulrizka Iskandar, Marina Sulastiana, (2015) namely spiritualists, love and community building. The difference in egalitarian Nurdin Basrun besides having a spiritualist, love and community building, also has strength; (1) motivation and (2) the strength of being an icon, or the community's raw modle and regional leadership, city / district leadership work programs in Riau Islands.

2) Social construction of the image of Nurdin Basirun's egalitarian brand

Based on the analysis of the results of the above research, the important findings in this study, the social construction process of Nurdin Basrun's egalitarian brand image took place in 3 stages, namely the institutionalization process, along with that also occurred the externalization process. At the stage of formation of institutionalization, namely the occurrence of legitimacy processes and at the same time an objectivation process also occurs, as well as at the confirmation stage where the process of socialization occurs, where the process of internalization also occurs simultaneously.

Table 1. The simultaneous stage of social construction of the image of the egalitarian brand Nurdin Basirun

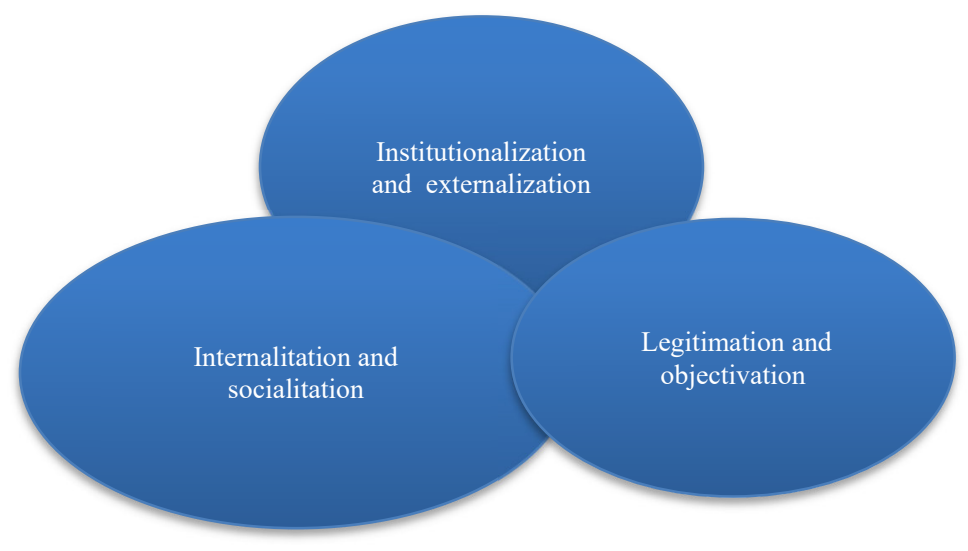

Based on an analysis of previous research and study data, there is a link between the stages of social construction described by Burhan (2018) and Berger and Luckmann (1968). That the two explanations have interrelated processes with each other like Table 7.1 above.

\section{References}

Amanda, G Ni Made Ras. (2014). Pertarungan Aktor Politik di Media Cetak Dalam Pemilukada Bangli 2010, Jurnal Universitas Indonesia.

Burhan Bungin. (2000). Konstruksi Soial Iklan Televisi dalam Masyarakat Kapitalistik, Disertasi. Program Pascasarjana Ilmu-Ilmu Sosial Universitas Airlangga Surabaya

Burhan Bungin. (2018). Komunikasi Politik Pencitraan. The Social Construction of Public Administration. Jakarta Prenada media

Burhan Bungin (ed). (2001). Metode Penelitian Kualitatif, PT. Raja Grafindo Persada, Jakarta

Burhan Bungin. (2015). Metode Penelitian Kualitatif, untuk Komunikasi, Kebijakan Publik dan Ekonomi. Jakarta: Prenada Media 
Burhan Bungin. (2008). Konstruksi Sosial Media Massa, Kencana Prenada Media Group, Jakarta Eriyanto. (2002). Analisis Freming: Konstruksi, ideology, dan Politik Media, Klis, Yogyakarta

Eriyanto. (2001). Analisis Wacana: Pengantar Analisis Teks Media, Lkis, Yogyakarta

Hamad Ibnu. (2004). Konstruksi Realitas Politik dalam Media Massa, GRANIT, Jakarta

Hamad, Ibnu. (2004). Konstruksi Realitas Politik Dalam Media Massa Pemilu 1999, Makara, Sosial Humaniora, Vol.8. No.1 April.

Hamad Ibnu, Agus Sudibyo, Muhammad Qadari. (2001). Kabar-Kabar Kebencian Prasangka Agama di Media, ISAI, Jakarta

Kawuryan Magandaru Widhi. (2015). Konstruksi Realitas Otonomi Daerah Dalam Media Massa Cetak, Jurnal Universitas Indonesia

Littlejohn, Stephen dan, Karen A. Foss, Theories of Human Communication, Ninth Edition. (2008). Singapore: Cengage Learning

Luwarso Lukas, Samsuri, Siswowiharjo. (2004). Media dan Pemilu 2004, SEAPA, Jakarta

Macnamara, Jim. (1999). Strategi Jitu Menjinakan Media: Ada Saatnya Media Dihadapi, PT. Mitra Media Publisher, Jakarta.

Rusadi, Udi. (2015). Kajian Media. Isu Ideologis dalam Perspektif, teori dan metode, Jakarta: Rajafindo Persada

Salim, Agus. (2006). Teori \& Paradigma Penelitian Sosial Edisi Kedua, Jogyakarta, Tiara Wacana.

Severin J Warner, Tankard. W James. (2007). Teori Komuniasi: Sejarah, Metode, dan Terapan di Media Massa, Fajar Interpratama Offset, Jakarta

Siahaan, Hotman M. (2001). Pers Yang Gamang, Lembaga Studi Perubahan Sosial Surabaya.

Singarimbun. (1999). Masri. Metode Penelitian Survei, Edisi Revisi LP3ES, Jakarta

Sudibyo, Agus. (2001). Politik Media dan Pertarungan Wacana, Lkis, Yogyakarta,

Sukandatrimidi. (2002). Metodelogi Penelitian "Petunjuk Praktis Untuk Peneliti Pemula" Gajah Mada University Press, September.

Wirawan, I.B. (2012). Teori-Teori Sosial Dalam Tiga Paradigma, Kencana Prenada Media Group, Jakarta.

A.Zulkarnain \& Syamsuddin Harris. (2017). Fenomena Blusukan dalam Model Kepemimpinan

Angervil, Gilvert. (2015). "Challenges to the Functionalism-Positivism and Social

Box, Richard C.(1999)."Running Government Like a Business: Implications for Public Administration Theory and Practice", The American Review of Public Administration 1999 29: 19.

Bourgon, Jocelyne,(2007)."Responsive, Responsible and Respected Government: Towards a New Public Administration Theory", International Review of Administrative Sciences 73(1). Vol 73(1):7-26.

Berger, Peter L. \& Luckmann, Thomas, (1991), "The Social Construction of Reality: A Treatise in the Sociology of Knowledg", Penguin Books.

Berman, Evan M.,(2009). "The New Face of Government: How Public Managers are Forging a New Approach to Governance”. Auerbach Publications Taylor \& Francis Group.

Burhan, Bungin. (2018). Komunikasi Politik Pencitraan: The Social Contruction of Public Administration (SCoPA).Jakarta, Prenadamedia Group.

Cox, Robert Henry.(2001)."The Social Construction of an Imperative Why Welfare Reform Happened in Denmark and the Netherlands but Not in Germany", World Politics 53 (April 2001), 463-98.

Christiansen,Thomas, Jorgensen,Knud Erik \& Wiener, Antje.(2011). "The Social Construction of Europe", Journal of European Public Policy, 6:4, 528-544.

Collins, Harry.(2016).“Social Construction of Reality”, Springer Science Business Media Dordrecht. Citra, Orwela. (2017). Branding Pemimpin Nasionalis Basuki Tjahaya Purnama dalam Debat Pilkada Dki Jakarta 2017 (menurut kode-kode televisi john fiske), Mediakita Vol. 1 No. 2 Juli 2017 | 157-171.

Creswell, John W. (2003). Research Design: Quantitative, Qualitative, and Mixed Methods Approaches. London: Sage Publications.

Cregård, Anna. (2017). Investigating the risks of spiritual leadership, Nonprofit Management \& Leadership C 2017.

Ghodeswar, B. M. (2008). Building brand identity in competitive markets: a conceptual model. Journal of Product \& Brand Management, 17(1), 4-12.

Geger Riyanto. (2009). Peter L. Beger: Perspektif Metateori Pemikiran, Jakarta: Pustaka LP3ES Indonesia.

Idris Hemay \& Aris Munandar. (2016). Politik Identitas dan Pencitraan Kandidat Gubernur terhadap Perilaku Pemilih. Jurnal Politik. 1737 VOL. 12 No. 01.

Ilkay Karaduman. (2013). The effect of social media on personal branding efforts of top level executives, Procedia - Social and Behavioral Sciences 99 (2013) 465 - 4731877-0428

Jun, Jong S. (2006). "The Social Construction of Public Administration", State University of New York Press.

Kristina Muhhina. (2015). "Governing "Transition": The Discursive Construction of Public Administration in Post-Cold War Estonia”, Administration \& Society 1- 37.

Kotler, Philip. (2003). Marketing Management, 11th Edition. Upper Saddle River, New Jersey: Pearson Education, 
Inc.

Kellis, Dana S.. (2012). Modern leadership principles for public administration: time to move forward, Journal of Public Affairs Volume 13 Number 1 pp 130-141

Marston, Sallie A. (2000). "The Social Construction of Scale”, Progress in Human Geography 24, 2 (2000) pp. 219-242.

Rony Setiawan, Suryana Sumantri, Tb. Zulrizka Iskandar, Marina Sulastiana (2015), Pengaruh Kepemimpinan Pelayan terhadap Kinerja Pelayanan Publik Pegawai Negeri Sipil pada Pemerintah Kota Bekasi, Fakultas Psikologi, Universitas Padjadjaran Bandung(C 2015 Psychology Forum UMM, ISBN: 978-979-796-324-8 